\title{
Benign intracranial hypertension associated to blood coagulation
} derangements

\author{
Domenico De Lucia1, Marisanta Napolitano1, Pierpaolo Di Micco*2,3, \\ Alferio Niglio ${ }^{4}$, Andrea Fontanella ${ }^{2}$ and Giuseppe Di lorio ${ }^{5}$
}

\begin{abstract}
Address: ${ }^{1}$ Division of Pathology, Second University of Naples, Naples, Italy, ${ }^{2}$ Internal Medicine Division, Buonconsiglio Fatebenefratelli Hospital of Naples, Naples, Italy, ${ }^{3}$ Biochemistry and Biotechnology Department and Ceinge Scarl, "Federico II", University of Naples, Naples, Italy, ${ }^{4}$ Division of Internal Medicine Second University of Naples, Naples, Italy and ${ }^{5}$ Center for Migraine; Second University of Naples, Naples, Italy

Email: Domenico De Lucia - pdimicco@libero.it; Marisanta Napolitano - pdimicco@libero.it; Pierpaolo Di Micco* - pdimicco@libero.it; Alferio Niglio - pdimicco@libero.it; Andrea Fontanella - pdimicco@libero.it; Giuseppe Di lorio - pdimicco@libero.it

* Corresponding author
\end{abstract}

Published: 24 December 2006

Thrombosis Journal 2006, 4:2I doi:10.1 186/|477-9560-4-2I
Received: 05 May 2006

Accepted: 24 December 2006

This article is available from: http://www.biomedcentral.com/I477-9560/4/2I

(C) 2006 De Lucia et al; licensee BioMed Central Ltd.

This is an Open Access article distributed under the terms of the Creative Commons Attribution License (http://creativecommons.org/licenses/by/2.0), which permits unrestricted use, distribution, and reproduction in any medium, provided the original work is properly cited.

\begin{abstract}
Background: Benign Intracranial Hypertension (BIH) may be caused, at least in part, by intracranial sinus thrombosis. Thrombosis is normally due to derangements in blood coagulation cascade which may predispose to abnormal clotting activation or deficiency in natural inhibitors' control. The aim of the study is to examine the strength of the association between risk factors for thrombosis and $\mathrm{BIH}$.
\end{abstract}

Patients and methods: The incidence of prothrombotic abnormalities among a randomly investigated cohort of 17 patients with $\mathrm{BIH}$, was compared with $5 \mathrm{I}$ healthy subjects matched for sex, age, body mass index, height and social background.

Results: The number of subjects with protein $C$ deficiency was significantly higher in patients than in controls ( 3 vs I, $\mathrm{p}<.00 \mathrm{I}$; Fisher Exact Test). Moderate to high titers of anticardiolipin antibodies ( $32-$-Glycoprotein type I) were found in 8 out of 17 patients.

Increased plasma levels of prothrombin fragment I+2, fibrinopeptide A (FPA), and PAI-I were demonstrated in patients group $(5.7 \pm 1.15 \mathrm{nM}$ vs $0.45 \pm 0.35 \mathrm{nM} ; 8.7 \pm 2.5 \mathrm{ng} / \mathrm{mL}$ vs $2.2 \pm 1.25 \mathrm{ng} /$ $\mathrm{mL} ; 45.7 \pm 12.5 \mathrm{ng} / \mathrm{mL}$ vs $8.5 \pm 6.7 \mathrm{ng} / \mathrm{mL}$, respectively; $\mathrm{p}<.00$; Fisher Exact Test). Gene polymorphisms for factor $V$ Leiden mutation, prothrombin mutation $20210 \mathrm{~A} / \mathrm{G}$, MTHFR $677 \mathrm{Cl}$ T, PAI-I 4G/5G, ACE I/D were detected in I3 patients.

Discussion: In agreement with other authors our data suggest a state of hypercoagulability in BIH associated with gene polymorphisms. Our findings also showed that mutations in cardiovascular genes significantly discriminate subjects with a BIH history. The association between coagulation and gene derangements, usually regarded to as cryptogenic, may suggest a possible pathogenetic mechanism in BlH. So, a prothrombotic tendency may exist that would, at least in part, explain some cases of $\mathrm{BIH}$.

Although based on a small population, these findings raise the exciting possibility of using these haemostatic factors as markers for selecting high-risk subjects in $\mathrm{BIH}$ disease. 


\section{Background}

Benign Intracranial Hypertension (BIH) is due to an increased intracranial pressure of unknown origin [1]. One of the possible causes of BIH may be due to intracranial venous sinus thrombosis [2], although cerebral angiograms could be normal in patients affected by $\mathrm{BIH}$ associated with conditions highly predisposing to venous thrombosis. This raises the possibility that unrecognised non-occlusive venous thrombus might impede cerebral spinal fluid (CSF) drainage [3].

Thrombosis is normally due to derangements in coagulation system which may predispose to abnormal clotting activation or to a deficient control of natural clotting inhibitors $[4,5]$. The risk of thrombosis is increased by factors that cause hypercoagulability or venous stasis, such as oral contraceptives, pregnancy or post-partum period, trauma, prolonged immobilization. However, the risk of thrombosis is also increased by hypercoagulable states due to inherited abnormalities of the coagulation system, such as factor V (FV) R506Q mutation, which causes resistance to activated protein $\mathrm{C}$ (PC) [6], prothrombin A20210G gene polymoprphism [7], and deficiencies of antithrombin III (AT III), PC or protein S (PS) [8]. Acquired abnormalities such as the presence of antiphospholipid antibodies can also induce an increased risk of thrombosis [9].

Increased plasma levels of the main inhibitor of fibrinolysis, plasminogen activator inhibitor type 1 (PAI-1), have been documented in subjects who subsequently developed myocardial infarction [10], while its association with venous thromboembolism is still matter of discussion.

The renin-angiotensin pathway plays a role in the regulation of PAI-1 plasma levels [11]. An insertion (I)/deletion (D) polymorphism of the angiotensin-convertying enzyme (ACE) gene has been related to plasma and cellular ACE levels [12]. Compared to the DD frequency in a control population, the frequency of the ACE DD genotype is higher in individuals with ischemic cardiovascular disease suggesting that ACE gene variant may contribute to the pathogenesis of this disease.

The $\mathrm{C} \rightarrow \mathrm{T} 677$ transition in the methylen-thetrahydropholate reductase (MTHFR) gene [13] have widened the spectrum of inherited thrombophilia through hyperhomocysteinemia.

So an activation of blood coagulation may predispose to thrombin formation and fibrin deposition that may lead to thrombosis of large or small vessels.
In this study, we examined the strength of the association between risk factors for thrombosis and BIH disease.

\section{Patients and methods Patients}

Seventeen unrelated patients with a documented diagnosis of idiopathic benign intracranial hypertension (BIH) according to World Health Organization criteria were studied retrospectively ( 4 men and 13 women; median age 31 years; range 15 to 55). They were referred to our thrombosis laboratory between February 1998 and May 1999 for a complete screening.

None of them had overt evidence of autoimmune or neoplastic disease. Subjects under anticoagulant or contraceptive treatment were previously excluded from the study.

The clinical records and the objective documentations of $\mathrm{BIH}$ were reviewed by two neurologists to confirm the diagnosis, based on clinical symptoms and signs of increased intracranial pressure (i.e. increased cerebrospinal fluid pressure, Computed Tomography and Nuclear Magnetic Resonance imagines with normal to small symmetrical ventricles).

\section{Healthy controls}

Fifty-one healthy persons (30 men and 21 women; median age 32; range 19 to 52)_matched for sex, age, geographic origin, and level of education were enrolled as healthy controls in the study. They came from a population of biologically unrelated friends of the patients.

A thorough anamnesis was recorded for both patients and controls in order to know common risk factors for cardiovascular diseases (i.e. smoking, hypertension, diabetes, dyslipidemia, oral contraceptives use, personal and $\backslash$ or familial history of venous thromboembolism or cardiocerebrovascular disease.

All subjects (i.e. patients and healthy controls) gave their written informed consent to the study.

\section{Laboratory tests}

Blood samplings were performed for both cases and controls before 10.00 a.m. with subjects fasting and having rested for at least 20 minutes. Blood was collected in vacuum tubes contaning 3.8 percent (wt/vol) sodium citrate as anticoagulant. Plasma was then obtained by centrifugation at $2000 \times \mathrm{g}$ for 20 minutes, swap-frozen in liquid nitrogen and stored at $-80^{\circ} \mathrm{C}$ within $2 \mathrm{~h}$ from collection. Blood samples in cases were collected between 6 and 24 months after the acute episode.

All cases were receiving secondary prophylaxis with either aspirin or ticlopidine, and none of them was on anticoag- 
ulant treatment with either warfarin or low molecular weight heparin. Laboratory measurements were subsequently performed in both cases and controls within 1 month from blood collection.

Prothrombin Time (PT) and Activated Partial Thromboplastin Time (APTT) were carried out according to Manifacturers recommendations. Fibrinogen (Fg) plasma levels were assayed by the Clauss functional method. All the measurements were determined on an automated coagulometer (ACL 2000, Instrumentation Laboratory, Milan).

Antithrombin III (ATIII) and Plasminogen (PLG) were determined by chromogenic methods (Chromogenix, Molndal; Sweden).

Antithrombin was further characterized by measuring antigen levels by immunoelectrophoresis with a policlonal antibody (Stago, Asmieres; France). Protein C (PC) activity was assayed by a clotting assay (Pro Clot, Instrumentation Laboratory, Milan; Italy). Protein C antigen levels were also measured by enzyme-linked immunosorbent assay (ELISA) with polyclonal antibodies (Dako, Glostrup; Denmark). Total protein S (total-PS) antigen was measured by ELISA with polyclonal antibodies (Dako). Free protein S (free-PS) was measured in the same way after precipitation of the $\mathrm{C} 4$ binding protein-protein S complex with polyethylene glycol 6000 (final concentration 3.5 percent) or directly by ELISA with a commercial kit that uses a specific monoclonal antibody (Asserachrom Free Protein S, Stago; France).

The diagnosis of poor response to anticoagulant action of activated protein $\mathrm{C}$ employed an APTT assay according to Dahlback and colleagues, with and without activated PC and in presence of an immunodepleted FV plasma (Instrumentation Laboratory; Milan) [14].

(Bouty, Milan; Italy) and Plasminogen Activator Inhibitor Type I (PAI-I) antigen levels were measured by ELISA (Bouty, Milan; Italy).

The measurements of prothrombin fragment $1+2(\mathrm{~F} 1+2)$, fibrinopeptide A (FPA) were assayed using an enzymelinked immunosorbent test (ELISA method) (Enzygnost, Bhering, Scoppito, Italy), while Dimers-D (D-Dimer [s]) were tested with a specific kit (DILA HemosIL Dimertest Latex, Instrumental Laboratory, Milan, Italy).

DNA was extracted from peripheral blood using standard international procedures.
DNA analysis to identify a transition from guanine to adenine at position 1691 in the coagulation factor $V$ gene was carried out as described by de Ronde and Bertina [15].

Screening for the MTMFR C->T 677 substitution was performed by amplification of a 198 bp DNA fragment followed by Hinf I digestion as described with modifications [13].

The PAI-1 4G/5G polymorphism was evaluated as previously reported [16].

The PCR technique, primers, and experimental conditions employed for the ACE genotyping were the ones suggested by Rigat et al. with some modifications [17].

\section{Statistical analysis}

All the computations were perfomed according to the Statistical Package for Social Science (SPSS 6.1 for Macintosh) [18].

The frequencies of the alleles and genotypes among cases and controls were counted and compared by the chisquare test with the values predicted by assumption of the Hardy-Weinberg equilibrium. Chi-square analysis or Fisher exact-test were used to compare differences between discrete parameters. The differences between cases and controls were analysed by impaired Student's test for coagulation parameters, and by the Kruskall-Wallis test for age, according to their observed distribution. Multiple logistic analysis was performed by using LOGISTIC procedure for SPSS.

All the results are given as mean \pm standard deviation (SD). A value of $\mathrm{p}<0.05$ was considered significant.

\section{Results}

Clinical characteristics of studied subjects as a whole are shown in Table 1. Cases had the same age of healthy subjects; there was the same number of smokers among patients and controls and less often alcohol consumers (O.R. 0.55; 95\% C.I., 0.21 to 0.65). Among subjects with pseudotumor cerebri there was a higher proportion of diabetics (O.R. 5.75; 95\% C.I., 3.01 to 7.45), hypertensives (O.R. 8.11; 95\% C.I., 3.40 to 18.15 ).

The two groups also differed for the number of hyperlipedemics (O.R. 6.25; 95\% C.I., 4.05 to 8.72 ) and users of oral contraceptives (O.R. 5.15; 95\% C.I., 3.65 to 7.21 ).

In addition, more frequently than controls, cases had an episode of venous thromboembolism (O.R. 7.60; 95\% C.I., 3.50 to 16.05 ) and a family history of ischemic stroke (O.R. 9.15; 95\% C.I., 6.75 to 17.05 ). 
Table I: Clinical Characteristics of patients and healthy subjects

\begin{tabular}{lll}
\hline & Patients (I7) & Healthy Controls (5I) \\
\hline Men & 4 & 30 \\
Women & 13 & 21 \\
Age (IQR) & $31(I 5-55)$ & $32(19-5 I)$ \\
\hline
\end{tabular}

PT, APTT, and fibrinogen levels were similar among the two different groups of subjects, such as levels of plasminogen and t-PA.

No control or patient carried inherited abnormalities of antithrombin III or PS. The number of subjects with PC deficiency was significantly higher in patients than in controls (3 vs. 1 p $<0.001$, Fisher Exact test).

Among controls only one subject showed a poor response to APC with FV gene R506Q mutation at heterozygous state (Table 2). Among cases, 2 individuals showed a poor response to anticoagulant action of APC $(<0.75$, which represents the cut-off point in our general population). One patient carried FV mutation R506Q at heterozygous state; the other subject did not show any mutation in FV gene, thus showing an acquired APC-resistance.

Moderate to high titers of IgG and IgM anticardiolipin antibodies ( $\beta 2$ GPI) were formed in 8 out of 17 patients (above the cut-off point of 10.5 U GPL/L and 9.5 U MPL/ $\mathrm{L}$, respectively). Among cases the mean values $\pm \mathrm{SD}$ of Ig G $\beta 2$ GPI and IG M $\beta 2$ GPI were $22.5 \pm 11.5 \mathrm{U}$ GPL/mL and $14.5 \pm 6.8 \mathrm{U} \mathrm{MPL} / \mathrm{mL}$ respectively. Among controls the mean values \pm SD of Ig G $\beta 2$ GPI and Ig M $\beta 2$ GPI were
$0.58 \pm 0.30 \mathrm{U} \mathrm{GPL} / \mathrm{mL}$ and $0.38 \pm 0.25 \mathrm{U} \mathrm{MPL} / \mathrm{mL}$, respectively $(\mathrm{p}<.001$ and $\mathrm{p}<.001$, Fisher Exact test).

Increased plasma levels of prothrombin fragment $1+2$, FPA, D-Dimer(s) and PAI were demonstrated in patients group $(5.7 \pm 1.15 \mathrm{nM}$ vs. $0.45 \pm 0.35 \mathrm{nM}, 8.7 \pm 2.5 \mathrm{ng} / \mathrm{mL}$ vs. $2.2 \pm 1.25 \mathrm{ng} / \mathrm{mL} ; 375 \pm 65 \mathrm{ng} / \mathrm{mL}$ vs. $225 \pm 75 \mathrm{ng} / \mathrm{mL}$; $45.7 \pm 12.5 \mathrm{ng} / \mathrm{mL}$ vs $8.5 \pm 6.7 \mathrm{ng} / \mathrm{mL}$, respectively; Fisher Exact test).

As shown in Table 3, carriers of the FV R506Q mutation were $1(6 \%)$ at heterozygous state among cases, and 1 $(2 \%)$ at heterozygous state among controls. The O.R. associated with FV R506Q was 3.7 (95\% C.I., 1.78 to 5.75 $\left.\mathrm{X}^{2}=6.2, \mathrm{p}=.01\right)$.

DNA analysis for the prothrombin A 20210 mutation demonstrated 1 heterozygous carrier ( $6 \%$, 95\% C.I., 2.05 to $9.55 ; \mathrm{X}^{2}=6.2, \mathrm{p}=.012$ ) among patients and 1 heterozygous carrier among healthy subjects (2 \%, 95\% C.I., 1.05 to 3.65). Among patients, 3 individuals (18\%, 95\% C.I., 12.05 to $24.55 ; \mathrm{X}^{2}=9.6, \mathrm{p}=.002$ ) were homozygous for the $\mathrm{T}$ allele of the MTHFR gene and 7 individuals (41 $\%, 95 \%$ C.I., 24.05 to $59.55 ; \mathrm{X}^{2}=13.4, \mathrm{p}=<.0001$ ) were heterozygotes for the same defect vs 6 subjects (12\%, $95 \%$ C.I., 7.35 to 17.65 ) with homozygosity for the $\mathrm{T}$

Table 2: Haemostatic parameters in pztients with BIH and controls. Values are expressed as main \pm SD

\begin{tabular}{|c|c|c|c|}
\hline & Patients & Healthy Controls & $P$ value \\
\hline PT(sec) & $12 \pm 0,5$ & $11,5 \pm 0,8$ & $0.18, \mathrm{~ns}$ \\
\hline aPTT (sec) & $30 \pm 2,5$ & $3 I, 5 \pm 3,4$ & $0.09, \mathrm{~ns}$ \\
\hline Fibrinogen (mg/dl) & $340 \pm 80,7$ & $360 \pm 68,2$ & $0.32, \mathrm{~ns}$ \\
\hline ATIII (\%) & $72 \pm 16,5$ & $76 \pm 14,7$ & $0.34, \mathrm{~ns}$ \\
\hline PG (\%) & $80 \pm 14,7$ & $74,5 \pm 15,2$ & $0.19, \mathrm{~ns}$ \\
\hline $\mathrm{t}-\mathrm{PA}(\mathrm{ng} / \mathrm{ml})$ & $6,8 \pm 3,7$ & $7,5 \pm 4,8$ & $0.58, \mathrm{~ns}$ \\
\hline PAI-I(ng/ml) & $45.7 \pm 12.5$ & $8.5 \pm 6.7$ & $<0.0001, \mathrm{~s}$ \\
\hline FPA (ng/ml) & $8.7 \pm 2.5$ & $2.2 \pm 1.25$ & $<0.0001, \mathrm{~s}$ \\
\hline $\mathrm{FI}+2(\mathrm{nM} / \mathrm{l})$ & $5.7 \pm 1.15$ & $0.45 \pm 0.35$ & $0.000 \mathrm{I}, \mathrm{s}$ \\
\hline D-dimers ( $\mathrm{ng} / \mathrm{ml})$ & $375 \pm 65$ & $225 \pm 75$ & $<0.000 \mathrm{I}, \mathrm{s}$ \\
\hline $\mathrm{PC}(\%)$ & $64 \pm 7.5$ & $87 \pm 14.5$ & $<0.0001$, s \\
\hline PS (\%) & $97 \pm 23$ & $103 \pm 12$ & $0.16, \mathrm{~ns}$ \\
\hline $\mathrm{A} \beta_{2} \lg M(\mathrm{UM} / \mathrm{I})$ & $14.5 \pm 6.8$ & $0.38 \pm 0.25$ & $<0.0001, \mathrm{~s}$ \\
\hline$A \beta_{2} \lg G(U G / I)$ & $22.5 \pm 11.5$ & $0.58 \pm 0.30$ & $<0.0001$, s \\
\hline
\end{tabular}

Prothrombin Time: PT; Activated Partial Prothrombin Time: aPTT;

Antithrombin: AT III, Plasminogen: PG; tissue-Plasminogen Activator; t-PA, Plasminogen Activator Inhibitor type-I: PAI-I; Fibrinopeptide-A: FPA; Prothrombin Fragment I+2: FI+2; Protein C activity: PC; Protein S activity: PS; IgM anticardiolipin antibodies Ig $M$ and Ig G: $A \beta_{2} \lg M$ and $A \beta_{2} \lg G ; s$ : significant; ns: not significant. 
Table 3: Mutational state frequence for FV R506Q, PT G202 I0A, MTHFR C677T, PAI-I 4G/5G, ACE I/D genes in patients and healhty subjects (HS).

\begin{tabular}{lllllll}
\hline Gene coagulation mutations & \multicolumn{3}{c}{ Homozygous Wilde-type } & Heterozygous & Homozygous Mutated \\
\hline & Patients (I7) & HS (5I) & Patients (I7) & HS (5I) & Patients (I7) & HS (5I) \\
FV R506Q & $94 \%$ & $98 \%$ & $6 \%$ & $2 \%$ & - & - \\
PT G202I0A & $94 \%$ & $98 \%$ & $6 \%$ & $2 \%$ & - & - \\
MTHFR C677T & $41 \%$ & $57 \%$ & $41 \%$ & $31 \%$ & $18 \%$ & $12 \%$ \\
PAI-I 4G/5G & $47 \%$ & $30 \%$ & $35 \%$ & $51 \%$ & $18 \%$ & $19 \%$ \\
ACE I/D & $30 \%$ & $46 \%$ & $47 \%$ & $43 \%$ & $23 \%$ & $11 \%$ \\
\hline
\end{tabular}

FV R506Q: factor $V$ Leiden gene polimorphism

PT G202 IOA: prothrombin G20210A gene polymorphism

MTHFR C677T: Methylenetetrahydrofolate reductase C677T gene polymorphism

PAl-I 4G/5G: plasminogen activator inihibitor I 4GI5G gene polymorphism

$A C E N D$ : angiotensin converting enzyme insertionldeletion gene polymorphism

allele of the MTHFR gene and 16 subjects with heterozigosity of control group (31\%, 95\% C.I., 19.05 to 46.07).

Genotype analysis of the PAI-1 gene showed that 6 subjects were heterozygous for $4 \mathrm{G} / 5 \mathrm{G}$ polymorphism among patients (35\%, 95\% C.I., 21.05 to $39.60 ; \mathrm{X}^{2}=3.5, \mathrm{p}=.06$ ) and 3 subjects among patients showed homozygosity for 4G allele $\left(18 \%\right.$, 95\% C.I., 12.25 to $23.15 ; \mathrm{X}^{2}=5.03, \mathrm{p}=$ .02 ), while 26 individuals were heterozygous for $4 \mathrm{G} / 5 \mathrm{G}$ gene polymorphism (51\%, 95\% C.I., 38.75 to 69.04$)$ and 10 were homozygotes for $4 \mathrm{G}$ allele (19 \%, 95\% C.I., 11.85 to 24.14) among controls.

ACE gene I/D polymorphism was evidenciated in 8 patients at heterozygous state (I/D, $47 \%$, 95\% C.I., 31.05 to $\left.57.20 ; \mathrm{X}^{2}=10.08, \mathrm{p}=.001\right)$ and in 4 patients at homozygous state (D/D $23 \%, 95 \%$ C.I., 14.15 to 33.45; $\left.\mathrm{X}^{2}=15.55, \mathrm{p}=<.0001\right)$ while 22 healthy subjects were heterozygotes for the same mutation (43\%, 95\% C.I., 28.85 to 61.25 ) and 7 healthy subjects were homozygotes (11\%, 95\% C.I., 2.05 to 9.55 ).

\section{Discussion}

Abnormalities of the clotting system such as natural anticoagulant deficiencies, resistance to anticoagulant action of APC, derangements in fibrinolytic pathway or an hypercoagulable state have been recognized as clear risk factors for venous thromboembolism [8]. Their role, however, in BIH is still matter of discussion [19].

Recent findings have suggested that intracranial venous sinus thrombosis, favoured by thrombophilia/hypofibrinolysis, may cause $\mathrm{BIH}$, determining an obstruction to cerebro-spinal fluid resorption-outflow [20].

On this topic, Sussmon et al. already reported that a state of hypercoagulability may exist in BIH disease [2].
Therefore, this state may also be associated with some mutations of the genes predisposing to hypercoagulability such as FV R506Q and FII G20210A and the C677T polymorphism in MTHFR gene and cardiovascular genes such as PAI-1 4G/5G and ACE gene I/D mutation. Moreover, also an association with antiphospholid antibodies has been found in our results so acquired thrombophilia should be considered; antiphospholipid syndrome in fact may be associated also to several impairments of central nervous system besides stroke [21].

Our results, throwing light on a compromised haemostatic balance equilibrium, provide new insights into the pathogenesis of BIH disease, which may be associated with high plasma levels in D-Dimer(s), PAI-1, F1+2 and FPA other than cytologic or chemical abnormalities of CSF that are able to contribute to the signs and symptoms of BIH.

The observation of hypercoagulable state and gene polymorphisms in a group of patients with BIH disease may also suggest the hypothesis of an association between coagulation derangements and venous thrombosis in BIH pathogenesis.

This hypothesis must be interpreted, however, with caution, because of the absence of objective instrumental findings in patients with BIH demonstrating the possibility that unrecognised non occlusive venous cerebral thrombus might impede CSF drainage as well as the high prevalence of gene polymorphisms predisposing to thrombophilia in the general healthy population. Furthermore, another limitation of our study may be find in the statistical model because the small number of enrolled patients compared with an increased of matched controls but this limit may be due to in part to the severe criteria that allow BIH diagnosis after a clinical suspect.

In conclusion, according to our findings the association of hypercoagulability based on biochemical or genetic 
abnormalities and BIH is probably not coincidental, in particular in subjects with inherited thrombophilia. So, our data may suggest that some cases of pseudotumor cerebri may recognise a thrombotic pathogenesis; although based on a small population, our results, in fact, seem to underline a clear association between hypercoagulable state, confirmed both with markers of hypercoagulability (i.e. fibrinopeptide A, prothrombin fragment $1+2$ and DDimer) and with tests to look for inherited thrombophilia (i.e. factor V Leiden, prothrombin A20210G, PAI 4G/5G, ACE I/D, MTHFR C677T).

However, because based on a small population our data concerning the involvement of hypercoagulability in the development of BIH is intriguing and should be confirmed on large based randomized clinical trial because actually we have not chance to screen any type of asymptomatic subject potentially at risk of BIH.

\section{References}

I. Smith JL: Whence Pseudotumor Cerebri ? J Clin Neuro-ophtalmol 1985, 5:55-56.

2. Sussmon J, Leach M, Greaves M, Malie R, Davies-Jones GA: Potentially prothrombotic abnormalities of coagulation in benign intracranial hypertension. I Neurol Neurosurg Psichiatry 1997, 62(3):229-233.

3. Grun L, Vinker S, Amitel M, Amir T, Bar-Dayen Y, Levi Y, Schoenfeld $Y$ : Pseudotumor cerebri in Systemic Lupus Erythematosus Gemin. Arthritis Rheum 1995, 25(2): 103-108.

4. Furie B, Furie CB: Molecular and cellular biology of blood coagulation. N Eng J Med I992, 326( I 2):800-806.

5. Miletich JP, Prescott SM, White R, Majerus PW, Bovill EG: Inherited predisposition to thrombosis. Cell I993, 72:477-480.

6. Dahlback B: Physiological anticoagulation. Resistance to actived protein $\mathbf{C}$ and venous thromboembolism. J Clin Invest 1994, 94:923-927.

7. Margaglione M, Brancaccio V, Giuliani N, D'Andrea G, Cappucci G, lannaccone L, Vecchione G, Grandone E, Di Minno G: Increased risk of venous thrombosis in carriers of the prothrombin A20210 gene variant. Ann Intern Med 1998, 129:89-93.

8. De Stefano V, Leone G, Mastrangelo S, Tripodi A, Rodeghiero F, Costaman G, Barbui T, Finazzi G, Bizzi B, Mannucci PM: Clinical manifestation and management of inherited trombophilia: retrospective analysis and follow-up after diagnosis of $\mathbf{2 3 8}$ patients with congenital deficiency of antithrombin III, protein C, protein S. Thromb Haemostas 1994, 72:352-358.

9. Ames PRJ, Pyke S, lannaccone L, Brancaccio V: Antiphospholipid antibodies, haemostatic variables and thrombosis. A survey of I44 patients. Thromb Haemost 1995, 73:768-773.

10. Hamsten A, De Faire U, Walldius G, Dahlen G, Szamosi A, Landou C, Blomback M, Wiman B: Plasminogen activator inhibitor in plasma: risk factor for recurrent myocardial infarction. Lancet 1987, 8549(2):3-9.

II. Vaughan DE, Lazos SA, Tong K: Angiotensin II regulates the expression of plasminogen activator inhibitor-I in cultured endothelial cells: a potential link between the renin-angiotensin system and thrombosis. J Clin Invest 1995, 95:995-100I.

12. Cambien F, Poirier O, Lecerf L, Evans A, Cambou J, Arveilier D, Luc G, Bard JM, Ricard S, Tiret L, Amouyet P, Alhenc-Gelas F, Soubrier F: Deletion polymorphism in the gene for angiotensin-converting enzyme is a potent risk factor for myocardial infarction. Nature 1992, 359:641-644.

13. Margaglione M, D'Andrea G, D'addedda M, Giuliani N, Cappucci G, lannaccone L, Vecchione G, Grandone E, Brancaccio V, Di Minno G: The methylenetetrahydrofolate reductase TT677 genotype is associated with venous thrombosis independently of the coexistence of che FV Leiden and the prothrombin A2010 mutations. Thromb Haemost 1998, 79:907-91।.
14. Malm J, Laurell M, Nilsson IM, Dahlback B: Thromboebolic disease. Critical evaluation of laboratory investigation. Thromb Haemost 1992, 68(1):7-13.

15. Bertina RM, Koeleman BPC, Koester T, Rosendaal FR, Dirven RJ, de Ronde $\mathrm{H}$, van der Valden PA, Reitsma PH: Mutation in blood coagulation factor $\mathbf{V}$ associated with resistance to activated protein C. Nature 1994, 369:64-67.

16. Margaglione M, Di Minno G, Grandone E, Celentano E, Vecchione G, Cappucci G, Grilli M, Mancini FP, Postiglione A, Panico S, Mancini M: Plasma lipoprotein(a) levels in subjects attending a metabolic ward: discrimination between individuals with and without a history of ischemic stroke. Arterioscler Thromb Vasc Biol 1996, 16:120-128.

17. Rigat B, Hubert C, Corvol P, Soubrier F: PCR detection of the insertion/deletion polymorphism of the human angiotensin converting enzyme gene (DCPI) (dipeptidyl carboxypeptidase). Nucleic Acids Res 1992, 20:1433.

18. Armitage P, Berry G: Statistical Methods in Medical Research. 3rd edition. Oxford, UK: Blackwell; I994:292-30I.

19. Backhouse O, Metcalfe T, Goulding P, Mc Evoy M, Menage M: Factor V Leiden mutation in association with idiophatic intracranial hypertension. Br J Ophthalmol I998, 82:844.

20. Glueck C], Goldenberg N, Golnik K, Sieve L, Wang P: Idiopathic intracranial hypertension: asscoaitions with thrombophilia and hypofibrinolysis in men. Clin Appl Thromb Hemost 2005, I I :44 I-448

21. Picillo U, Marcialis MR, Italiano G: Antiphospholipid sindrome. Current knowledge and our experiences. Int J Surg Sci 1999, 6: $118-125$.
Publish with Biomed Central and every scientist can read your work free of charge

"BioMed Central will be the most significant development for disseminating the results of biomedical research in our lifetime. "

Sir Paul Nurse, Cancer Research UK

Your research papers will be:

- available free of charge to the entire biomedical community

- peer reviewed and published immediately upon acceptance

- cited in PubMed and archived on PubMed Central

- yours - you keep the copyright
BioMedcentral 